\title{
Different Dimensions of Muslim Nationalism in South Asia Before the Establishment of Muslim League
}

\author{
Inayatullah Din \\ Master's student, Department of History, School of Social Sciences, \\ University of Hyderabad, Gachibowli, Telangana - 500046
}

\begin{abstract}
Muslim nationalism in South Asia didn't exist till the finish of the Muslim rule here. The decay of the Mughal Empire, the ascent of British Colonialism, and the political reassertion of Hindus in India furnished the materials with which Muslim nationalism would initially start to shape itself. This article intends to break down three unique dimensions of Muslim nationalism before the foundation of the Muslim league in 1906. In this article, an endeavour is made to discover how the Muslim leaders speaking to various developments responded to the troubles introduced by the colonial control, modernization, and the political reassertion of Hindus. The article will likewise observe the roles of characters like Syed Ahamad Barelvi, Sir Syed Ahamad Khan, and Sayyid Jamāl al-Dīn al-Afghānī in the development of political awareness among the Muslims and how it prompted Muslim nationalism.
\end{abstract}

Keywords: Muslim, Hindu, Nationalism, Colonialism.

DOI: $10.7176 / \mathrm{HRL} / 53-02$

Publication date: April $30^{\text {th }} 2021$

\section{Introduction}

'NATION', 'nationality', 'nationalism' -there is no more explosive set of words in modern political vocabulary, nor more polemical. Whether you are a political philosopher in search of a definition of 'nation' or a mere agitator claiming nationhood for your people, the concept eludes you. But elusiveness is one thing, inertness quite another (Aziz 1967:11). The establishment of Pakistan in 1947 opens the topic of the underlying foundations of Muslim nationalism (Prakash 2003). Muslim nationalism in India took its birth on the occasion when Muhammad bin Qasim, as the conqueror of Sind, hoisted the Muslim flag at Debul. It was the incident which was pointed out in the statement of Jinnah who said that Pakistan Movement started when first nonMuslim in India was converted to Islam (cited in Hussain, 2010). A non-Muslim individual embracing Islam did not matter much as a physical phenomenon. What mattered, in fact, was the advent of new Ideology (cited in ibid.). For the national movement drove by the Indian National Congress, the independence picked up implied a fragmented victory since the vision of a skillet Indian state was at last frustrated by the regional parcel. For the Muslim League, the proclamation of Pakistan was the materialization of the two-nation theory ${ }^{1}$, an ideal that reflected the culmination of the process of the ideological construction of Muslim nationalism in the Indian subcontinent (Rodriguez 2017). It was a time of enormous political, social, economic and cultural change which awakened a spirit of nationalism in the peoples of India (Avari 2013: 176). In this article, I analyze the initial period of the process of Muslim nationalism beginning with the ulema and masterminds like Syed Ahmad when they launched the mujahadeen movements against the British rule, which eventually alienated the community and made them permanent enemies in the eyes of the British. At that point, came the erudite people like Sir Syed, who started the instructive, scholarly, philosophical, social, and political patterns in his locale. Then the last thinker I'm concentrating on in this paper went by the name of Sayyid Jamāl al-Dīn al-Afghānī, who was also intrigued like Sir Syed by the western advancements. However, the principal distinction between the two is that Sir Syed wants the British rule to prevail, but the Afghani is someone who wanted to topple the framework by receiving western sciences and foundations that may fortify Islam.

\section{Objective of the study}

To study the different ideological dimensions of Muslim nationalism before the establishment of the Muslim league in 1906. To explore the social setting of Muslims in 19th-century colonial India. To study the contribution of three important Muslim personalities in the development of political awareness among Muslims.

Methodology: This paper is mainly based on secondary data. No primary data has been collected as a collection of primary data. For the collection of secondary data, available literature in the form of Books, Newspapers, along with published articles and research papers have been selected.

\footnotetext{
${ }^{1}$ The theory, enunciated by the poet and philosopher Muhammed Iqbal in 1930, considered Islam and Hinduism as two social orders with different and antagonistic cultural identities incapable of merging into a single nationality and living within the same state. Under that budget, Muslim identity became a pre-existing nation to claim its political recognition as a nation in its modern and western sense, and thereby justify the right to have a separate state (see Rodriguez 2017).
} 


\section{Muslim nationalism: fighting for the crescent, a religious start}

The developments drove by the Sunni ulama against the colonial rule long before the revolt of $1857^{1}$ comprise perhaps one of the earliest dimensions of the formation of Muslim nationalism in South Asia. They were resolved on a more aspiring arrangement of opposition. They appreciated the limits of their physical power as far as military resistance was concerned, but they were convinced that they could compensate for that weakness by awakening and revitalizing the Muslim masses with the traditional message of Islam based on Sunni principles and instilling in them the keenness for a jihad (Avari 2013: 159). The idea of a jihad against the Company first arose in the writings of a scholar and preacher, Shah Abd al-Aziz (1746-1824), the son of Shah Wali Allah (ibid., 160).

The ulema had just been permitted to assume an ostensible function during the statures of the Muslim rule in India in the activities of the state. However, as this standard subsided, the ulema took it upon themselves to air the aspirations and fears of the new Muslim community. The ulema insisted on explaining the decline of the Mughal Empire as a symptom of the deterioration of 'true Islam' in the region - due to the inclusive policies of the Mughals which strengthen the Hindus and extended patronage to Sufi saints and orders, and which, in turn, encouraged 'alien ideas' to seep into the beliefs and rituals of the region's Muslims (Paracha 2016). Such a mien saw various ulema and pastors from the developing Muslim people group become drawn towards an extreme puritan development that had mushroomed 2000 miles away in Arabia in the eighteenth century. It was driven by one Muhammad Al-Wahhab, a celebrant in the Nejd zone of focal Arabia, who lectured the ejection and dismissal of different practices and ceremonies from Islam, which he asserted were contortions and shocking developments. A Muslim researcher from Bengal Haji Shariatullah got stricken by Wahhab's development when he made a trip to and remained in Arabia in 1799. He was also the founder of the anti-zamindar movement, the Faraizi movement ${ }^{3}$ in Bengal but developed into a more violent campaign under his son, Dadu Miyan (cited in Avari, 2013). He was amazingly pompous of the conduct of the last leftovers of the Mughal Empire on his revisitation of India and guessed that the Muslims of India had been declining as a community mainly because of the way that they were practicing an inaccurate strain of Islam, which was debased by customs obtained from Hinduism.

Another Muslim thinker in such manner was Syed Ahmad Barelvi ${ }^{4}$ who, however, an impassioned supporter of Sufism, accepted that Sufism in India, as well, needed change and that this must be accomplished by once again introducing the significance of adhering to Sharia laws, something which one didn't anticipate from the historically heterogeneous Sufi orders in India. The Muslim condition was in decay, and Syed Ahmad argued that it was because the convictions of the basic Muslims of India spurned the idea of gaining political power through force. He recommended that this must be accomplished through the act of the Islamic idea of holy war, which was absent in the make-up of Islam in the subcontinent. Ironically, it was not the Company that was the first target of the jihad movement; it was, in fact, the Sikh kingdom of Punjab (cited in Avari, 2013). This kingdom, which had expanded and re-organized itself under a brilliant leader, Rana Ranjit Singh, and which was allied to the Company, put pressure on the Pathan tribes who inhabited the extreme north-western areas of the subcontinent. It was in order to help them that a dedicated disciple of Shah Abd al-Aziz, Sayyid Ahmad Barelvi, recruited a band of mujahids or fighters for Islam (cited in ibid.), and most of them belonged to various Pakhtun tribes (Paracha 2016). He entreated them to disregard their ancestral traditions and endeavour to battle a holy war against the 'unbelievers' (Sikhs and British) in the zone and assist him with setting up a state-run on Sharia

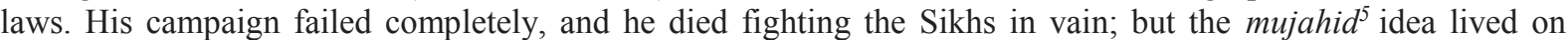
(Avari 2013: 160). The idea of 'purifying' Islam and Muslims in India formulated by men like Shariatullah and Syed Ahmad were expressions of the fears haunting the local Muslims (Paracha 2016). These apprehensions were likewise set off by the mushrooming of forceful Hindu reformist developments and furthermore by the appearance of Christian preachers from Britain. Men like Shariatullah and Syed Ahmad believed that the nature of Muslim convictions in India was such that it could be easily moulded by the missionaries and the Hindu reformists (ibid.). To them, just severe adherence to Islamic laws and ceremonies could spare the Muslim people

\footnotetext{
${ }^{1}$ The Great Revolt of 1857 is usually referred to as the "First War of Independence" by most historians from the Indian Subcontinent, and as the "Great Mutiny" by most of Western historians, particularly British.

${ }^{2} \mathrm{Jihad}$, in Islam, a meritorious struggle or effort. The exact meaning of the term jihād depends on context; it has often been erroneously translated in the West as "holy war." Jihad, particularly in the religious and ethical realm, primarily refers to the human struggle to promote what is right and to prevent what is wrong.

${ }^{3}$ The movement Shariatullah started came to be popularly known as the faraizi movement. His reform movement was basically religious; but it touched upon various other aspects of the society. He may be characterised as an Islamic revivalist, a social reformer and a populist peasant leader.

${ }^{4}$ Syed Ahmad Barelvi is considered one of the early Muslim freedom fighters of India and a great reviver and thinker of Islam in the Indian subcontinent. He is popularly known among the Indo-Pak Islamic clergy and ulema as a "shaheed" (a martyr of Islam) who led the Mujahideen movement in India (see Dehlvi 2016).

${ }^{5}$ Mujahideen, singular mujāhid, in its broadest sense, Muslims who fight on behalf of the faith or the Muslim community. In the 19th century the term became increasingly identified with the militant revivalist movement of Sayyid Ahmad Baralawī (Brelvi), whose self-styled mujāhidīn fought both Sikh expansion and British paramountcy in India
} 
group from being totally consumed by the changing political and social flows and functions. They made the mosques and madrassas the foundations of the possibility of nationhood among the local Muslims. When the British started to attest to their power, these developments eventually fell. These movements evoked a flood of enthusiasm among numerous Indian Muslims, yet these passions put the community on a course prompting further distance and social and political weakening, particularly after the 1857 Sepoys Mutiny against the British.

\section{Bearing the brunt and realizing the position}

The Muslims-stirred to the acknowledgment of their actual situation in India especially after the Mutiny of 1857. The exit of the last Mughal monarch from the throne of Delhi was not only a symbol of their downfall but also an end to their existence as a separate and dominant group in Indian political life (Aziz 1967: 18). A new phase in India's history opened after the 1857 rebellion and the consequent dissolution of the East India Company. The era of the colonial Raj began with Queen Victoria's proclamation of 1 November 1858. This benign document set a new tone of authority and conciliation (cited in Avari, 2013). The post-Great Revolt period was probably the gloomiest period in the history of the Muslim community in the Indian Subcontinent (Belkacem 2007-08: 44). Muslims had created and taken an unmistakable part in the events of 1857, in the British eyes, whereas Hindus kept a low profile. Therefore, the Muslims were to bear, alone, the fault. Two factors influenced the creation of this image: the first was, of course, the nature of the movements led by Shariatullah and Syed Ahmad decades before the Mutiny; and second was the lingering imagery in the West of Muslims authored by European Christian perseveres during the Crusades (1095-1291) (Paracha 2016). Quick and savage responses were to be incurred by the British administration, which would bring about a cruel reality for the Muslim people group. They lost their moorings, their confidence, their hope. And, for the first time, they realized with the anguish of bitterness that they were nothing but a weak, powerless, supine minority. This was the first casting of the seeds of nationalism, the first kindling of a feeling of loneliness and prostration, the first awakening to the need of solidarity (Aziz 1967: 18). So, these were the conditions under which the Muslim started to have a flickering of his nationhood.

\section{British raj energizes the community cognizance}

The very idiom of British rule after 1857 encouraged the development of political consciousness by religious communities (Hardy 1972: 116). Before the 1857 upheaval, the British, in their writings on India, generally considered India to be a racial whole. But things in this respect began to change drastically when the British (after 1857) began to investigate the social, political and cultural dynamics of the religious differences between the Muslims and the Hindus in the region, and then utilised their findings to exert more control over both the communities (Paracha 2016). One way through which Government encourages community consciousness among Muslims was through civil service to which, in the lower ranks at least, Indians were recruited on the basis of educational qualifications and professional skills, introduced new arenas of competition for power, patronage, and social prestige (Hardy 1972: 117). Noted historian Ayesha Jalal contends that the idea of both Muslim and Hindu nationalism, was to a great extent, the consequence of British social designing when they presented the entire idea of conducting a census. The outcome of the census was the somewhat conceptual arrangement of communities based on faith, developed through overwhelmingly intriguing statistics, embraced, not exclusively to fathom the mind-boggling nature of Indian society yet to likewise devise a basic method to more readily control it.

\section{Muslim nationalism: The judicious turn and the roots of Pakistan}

Sir Syed Ahmad Khan, the founder and intellectual pioneer of the second dimension of Muslim nationalism. And it is this dimension which evolved into becoming a movement that strived to carve out a separate Muslimmajority country in the subcontinent, and then further evolve to become Pakistani nationalism (Paracha 2016). Sir Syed is the one who acted with the tide of functions and established its framework in the unfriendly, undoubtedly threatening milieu of the 1880s (Aziz 1967). Sir Syed, though by no means consciously made possible the emergence of two most outstanding Muslim leaders who had enthusiastically started out as staunch Indian nationalists, ended up finally at the threshold of Muslim nationalism (Al Mujahid 1999: 87). Belonging to a family which had roots in the old Muslim nobility, Sir Syed's prolific authorship on the Muslim condition in India (during British rule) and his activism in the field of education, helped formulate nationalist ideas in the Muslims of the region. These ideas went on to impact and influence a plethora of Muslim intellectuals, scholars, politicians, poets, writers and journalists who then helped evolve Syed's concept of Muslim nationalism into becoming the ideological doctrine and soul of the very idea of Pakistan (Paracha 2016). It was Sir Syed that had initiated the educational, intellectual, ideological, cultural and political trends and engendered tendencies that laid the groundwork for a Muslim renaissance in India (Al Mujahid 1999: 87). It is certainly true to say that Sir Syed was too much impressed by western rationalism and wanted to show that every doctrine of Islam could measure up to all principles of science, reason, and common science. In doing this, he was trying to be both 
rationalist and a good Muslim (Sayeed 1998: 16). He was one of the first Muslim scholars to offer a point by point answer to British authors who were presenting and introducing the tradition of Islam as something which was damaging and retrogressive. Sir Syed reminded the British that Islam was inalienably a progressive and modern religion, and it had empowered and encouraged the study of philosophy and the sciences. He actively campaigned for the adoption of modern Western education in India, particularly for Muslims (cited in Avari, 2013). He both started and joined a number of organizations whose purpose was to make European knowledge accessible to young Muslims and other Indians in Urdu vernacular (cited in ibid.). Sayyid's services to his community may be summarized in three terse phrases: loyalty to the British, devotion to education, aloofness from politics (Aziz 1967: 19). He was intensely opposed to the actions of men like Shariatullah and Syed Ahmad Barelvi, and he was additionally disparaging of the 1857 uprising, proposing that such undertakings did more damage to Islam and the Muslims.

After 1857 Hindu people group had set up better relations with the British and was in a superior situation to shape into an all-encompassing network, so sir Syed rushed to get a handle on this reality and he contended that Muslims also need to communicate as a comprehensive network by emphatically reacting to the progressions being executed by the British in the social, legal and political circles of India. At the point when the British shaped the idea of community as a whole by clubbing together financially, ethnically assorted gatherings into unique Muslim, Hindu, and Sikh people group. Sir Syed, like reformers from different networks, localized the European idea of nationality to address the distinct partisan, class, ethnic, and social divisions inside Muslim people group. Sir Syed's sense of loyalty sprang from his reading of the Hindu-Muslim problem. Hindus and Muslims were two unequal 'nations', and the latter would ever remain a minority in India. Every advance towards democracy would mean the depression of the Muslims under the rule of the Hindu majority. Therefore, he opposed the introduction of parliamentary institutions as well as the increase in the recruitment of Indians to public service by open competition. Such political principles, he said, could only be applied to a country inhabited by one nation. In India every step towards a representative goal would be one more rivet in Muslim chains (Aziz 1967: 20). Sir Syed reprimanded ulema for compelling the Muslims to dismiss science. He composed that Muslims needed new religious philosophy of Islam, which was discerning and dismissed all doctrinal ideas that were in conflict with good judgment and reason.

\section{Muslim nationalism: Pan Islamism, Hindu-Muslim solidarity and enter of Al-Afghani}

The third dimension of Muslim nationalism in South Asia before the foundation of the Muslim league was panIslamism, which was introduced among the Muslims of India in the 19th century. Pan-Islamism is an ideology that emphasizes the solidarity of Muslim peoples worldwide (Avari 2013: 187). In its modern form, the ideology arose in the nineteenth-century Ottoman Empire, at a time when Turkey was facing political and military pressures from varied European nations (cited in Avari, 2013). One of its earliest advocates was Jamal Al-Din Al-Afghani ${ }^{1}$ - a bright young political activist, journalist, reformer, and Afghan ideologist who showed up in India in 1855 (Paracha 2016). He one of the most prescient of modern Muslim thinkers, who had travelled and preached across British India (Cited in Avari, 2013). In contrast to the conventional ulema, Afghani didn't perceive any great in turning inwards and drastically dismissing the modernity associated with British rule. His belief in the potency of a revived Islamic civilization in the face of European domination fundamentally impacted the development of Muslim thought in the nineteenth and early twentieth centuries. He recognized the matchless quality of Western education, however, accentuated that Muslims should grasp it to improve their parcel and afterward reverse the situation against Western imperialism by ousting it and setting up a worldwide Islamic caliphate. Al-Afghani held that Hindus and Muslims should work together to overthrow British rule in India (Alam 2011). He worked to transform Islam into a lever against western imperialism. Afghani was the prototype of the modern fundamentalist. Like Sir Syed, he also had been influenced by western rationalism and the ideological mode of western thought (Kramer 2017: 143). Afghani welded a traditional religious hostility towards unbelievers to a modern critique of western imperialism and an appeal for the unity of Islam, and while he inveighed against the west, he urged the adoption of those western sciences and institutions that might strengthen Islam (ibid., 143). Afghani saw Western innovation as a solution to recover regenerate the Muslims, not as an approach to assist them in discovering a spot inside colonial settings yet to completely comprehend and afterward eradicate imperialism. Afghani was rather progressive and modernistic in his thinking (Paracha 2016). A contemporary English admirer described Afghani as the leader of Islam's liberal religious reform movement (Kramer 2017: 143). The pan-Islamist thought which he spearheaded esteemed the significance of changing and reforming the Muslim mentality through modern scholarly methods, and afterward utilizing the transformed as a weapon against the political incomparability of Western imperialism.

\footnotetext{
${ }^{1}$ Jamal al-Din al-Afghani, Jewish Virtual Library, https://www.jewishvirtuallibrary.org/jamal-al-din-al-afghani (Accessed on 05 November 2020).
} 


\section{Conclusion}

To sum up, the rising Muslim nationalism of the nineteenth century took several peculiarities that determined largely its further development (Rodriguez 2017: 63). So, the earliest dimension of Muslim nationalism was overwhelmed by the ulema, and men like Syed khan endeavoured to club Muslims of India as a community that shared theological commonalities with Muslim communities elsewhere in the world. They also explained Muslims as a nation, however, not in the modern setting but rather as a part of a bigger Muslim ummah. They considered Islam to be a theistic route to a political revolution. The other dimension of Muslim nationalism called pan-Islamism represented by thinkers like Afghani, who considered Islam to be a trademark to mobilize Muslims around the globe against European colonialism and who was vocal in his revilements of the conventional ulema who were dismissing modern instruction; nonetheless, very like the ulema, Afghani as well considered the Muslims part of the worldwide Muslim community (ummah). The first dimension of Muslim nationalism produced demoralising results for the Muslims and made them an inherent enemy in the eyes of the British officials after the failure of the 1857 Mutiny. The other dimension represented by pan-Islamist thought evolved latter into an ideology which attempts to erect a global caliphate, not through a faith strengthened by progressive reform, but by a largely mythical understanding of the faith's bygone militaristic and moralistic splendour (Paracha 2016). The dimension of Muslim nationalism founded by Sir Syed was modern since it comprised the response of a part of the Muslim elites to the difficulties presented by the colonial domination and modernization; however, its establishment was connected to a religious and social separation that (Rodriguez 2017), under those conditions, took on another philosophical and political importance. Sir Syed received harsh criticism from both the supporters of Afghani's pan-Islamism as well as by the conservative ulema. Notwithstanding the assaults - which generally came his way through assertions, publications, and articles in the plenty of Urdu papers which started to come up after the multiplication of the print press in India (Paracha 2016) - it was his thoughts which figured out how to overwhelm the most noticeable dimensions of Muslim nationalism in India.

As indicated by Ayesha Jalal, Sir Syed's vital and down to earth arrangement with the British helped his plans to make indispensable in-streets in a more coordinated and more liberated way (Paracha 2016). His religious naysayers remained positioned in their mosques and madrassahs. Thusly, the greater part of his religious adversaries couldn't discover a spot in the school that he set up in Aligarh. This school evolved into becoming a college and then an institution which began to produce a specific Muslim world-class and metropolitan bourgeoisie who might go on to dominate Muslim nationalist thought in India and eventually decide the course in 1906 when the consciousness of Muslim nationalism took practical form when a deputation of Indian Muslims - Shimla Deputation ${ }^{1}$ - held a meeting with the Governor-General Lord Minto in Shimla and secured the viceroy's consent in respect of separate electorate for Muslims.

\section{References}

- Al Mujahid, Sharif. (1999), "Sir Syed Ahmad Khan and Muslim Nationalism in India", Islamic Studies, 38(1): 87-101.

- Alam, Arshad. (2011), "The Politics of Deoband”, outlook, 28 July 2011, https://www.outlookindia.com/website/story/the-politics-of-deoband/277847 (Accessed on 05 November 2020).

- Avari, Burjor. (2013), Islamic Civilization In south Asia A history of Muslim power and presence in the Indian subcontinent, London and New York: Routledge.

- Aziz, K.K. (1967), The Making of Pakistan A Study in Nationalism, London: Chatto \& Windus.

- Belkacem, Belmekki. (2007-08), "The Impact of British rule on the Indian Muslim community in the nineteenth century," ES, 28: 27-46.

- Dehlvi, Ghulam Rasool. (2016), "Syed Ahmad Rai Barelvi and the 18th century mujahidin movement in the Indian subcontinent", firstpost, 22 May 2016, https://www.firstpost.com/india/syed-ahmad-rai-barelvi-andthe-18th-century-mujahidin-movement-in-the-indian-subcontinent-2790982.html (Accessed on 03 November 2020).

- Hardy, P. (1972), The Muslims of British India, Cambridge: Cambridge University Press.

- Hussain, Mahboob. (2010), "Muslim nationalism in South Asia: Evolution through constitutional reforms",

\footnotetext{
${ }^{1}$ Shimla Deputation organised by the Indian Muslim leaders, met the Governor General and Viceroy lord Minto in Shimla on 1 October 1906 The aim of the deputation was to win the sympathies of the Raj on their side concerning matters relating to their interests as a community. The meeting was extremely significant. The demands the deputation put forward to lord Minto were: (a) employment of Muslims to Civil administration, the military and the Judiciary in sufficient numbers; no competitive examinations should bar employment to the higher posts; (b) preservation of a certain number of seats for Muslims in the municipal and district boards and in the university senate and syndicate; (c) separate election of Muslims to the Provincial council based on their political importance and not on the population ratio; (d) election of a sufficient number of Muslims to the Imperial Legislative council in order to avoid reducing the Muslims to an insignificant minority; and (e) establishment of a Muslim University which would stand as a glory to the religious and cultural life of the Muslims.
} 
Journal of Political Studies, 01(02): 65-77.

- Kramer, Martin. (2017), Arab Awakening and Islamic Revival: The Politics of Ideas in the Middle East, London and New York: Routledge.

- Paracha, Nadeem F. (2016), "The forgotten future: Sir Syed and the birth of Muslim nationalism in South Asia”, Dawn, 18 August 2016, https://www.dawn.com/news/1277341 (Accessed on 25 October 2020).

- Prakash, Om. (2003), "Roots of Islamic separatism in Indian subcontinent", Proceedings of the Indian History Congress, 64: 1049-1065

- Rodriguez, Enrique Baltar. (2017), “The origins of Muslim nationalism in British India, ” Journal of Arts \& Humanities, 06(05): 55-65.

- Sayeed, bin Khalid. (1998), Pakistan the formative phase 1857-1948, Karachi: Oxford University Press.

- Inayatullah Din

- Currently pursuing master's degree in History

- University of Hyderabad 